Special Issue of the 8th International Advances in Applied Physics and Materials Science Congress (APMAS 2018)

\title{
Plasma Nitriding Process of Cast Camshaft to Improve Wear Resistance
}

\author{
A. DAYAnÇ ${ }^{a, *}$, B. KARACA ${ }^{a}$ AND L.C. KumRUOĞLU ${ }^{b}$ \\ ${ }^{a}$ ESTAŞ Eksantrik San. ve Tic. A.Ş., 58060 Sivas, Turkey \\ ${ }^{b}$ Cumhuriyet University, Department of Metallurgy and Materials Eng., 58100 Sivas, Turkey
}

\begin{abstract}
The aim of this study was to investigate the effect of plasma nitriding heat treatment on the microstructure, hardness and abrasion resistance of the GG25 grade gray cast iron camshaft. For this purpose, in the first stage casting simulation was carried out by using NOVACAST computer software program of GG25 grade gray cast iron camshaft to optimize casting quality and production of camshaft with sand casting method. Casting process was performed between at $1410-1420^{\circ} \mathrm{C}$ and casting time was between $14-16$ s. Plasma nitriding was carried out for 120 minutes and 240 minutes for cast gray iron camshafts for each gas mixture at gas mixture ratios of $80 \% \mathrm{H}_{2}+20 \% \mathrm{~N}_{2}, 90 \% \mathrm{H}_{2}+10 \% \mathrm{~N}_{2}, 94 \% \mathrm{H}_{2}+6 \% \mathrm{~N}_{2}$ at $500{ }^{\circ} \mathrm{C}$. Plasma nitrided camshafts were subjected to optical microscopy, SEM, XRD analyzes and mechanical tests (hardness and wear). For the cas iron camshaft made from GG25 grade, the optimum hardness (583 HV0.1) and the wear resistance (1.90 mg/500 cycles), were obtained from the diffusion layer depth $(603 \mu \mathrm{m})$ and the white layer thickness $(10 \mu \mathrm{m})$ reached 240 min. plasma nitriding of the $94 \% \mathrm{H}_{2}+6 \% \mathrm{~N}_{2}$ gas mixture.
\end{abstract}

DOI: 10.12693/APhysPolA.135.793

PACS/topics: casting, plasma nitriding, tribological properties, SEM

\section{Introduction}

Camshafts are known as indispensable and durable parts of power transmission systems. High load bearing capacities, operating speeds and long service life are the most important features of these materials. The camshaft cams and rocker arms are in direct contact. The cam may be subject to abrasion during the rocking motion of the shaft. Worn surfaces will cause the valves to open less, the valves to run audibly and to open and close prematurely. As a result, the slightest change in the timing of the opening-closing of the valves results in poor combustion, thereby reducing the power of the motor [1-3].

The surface properties of materials have an important place in terms of their behavior in the environment in which they are used. Machine parts operate under severe working conditions, in particular, wear, corrosion, fatigue and high temperature. They can not fulfill the demands completely and are gradually deteriorated by mechanical and/or chemical effects [4].

Effective surface hardening without changing the chemical composition of the surface, the carbon content of the material must be sufficient for hardening [5].

Camshafts are vulnetable to wear in points of contact, and especially on cam surfaces. When lubrication is inadequate, wear loss becomes higher. For this reason, many studies have been carried out to improve the wear properties. In order to improve the wear resistance of gray cast iron, the material surface is hardened by heating to

*corresponding author; e-mail: ayhan.dayanc@estas.com.tr the austenitic phase transition temoerature and following by martensitic phase transformation by rapid cooling [6].

Thermochemical surface treatments such as plasma nitriding are widely used in order to effectively use the steels used in machinery manufacturing and to increase the service life. It is relatively low in application cost. The surface layer formed after the nitriding process and the diffusion layer formed beneath this layer improve the wear resistance of the material $[7,8]$.

In this study, the effects of plasma nitriding heat treatment on microstructure, hardness and tribological properties of GG25 cast iron camshafts were investigated.

\section{Materials and equipments}

Before casting of gray cast camshafts, liquid metal filling (Fig. 1) and possible traction cavities were simulated by $3 \mathrm{D}$ solid modeling of runners and feeders of sand mold casting models with NovaCast casting simulation system to eliminate casting defects. The production of the casting cam mill was carried out according to the process flow diagram (Fig. 2). Melting was carried out in induction furnaces and the metal analysis was controlled by Atas Thermal Analyzer. Inoculation was carried out at a temperature of $1460-1480^{\circ} \mathrm{C}$ in a liquid metal casting crucible, and casting was carried out at a temperature of $1400-1420^{\circ} \mathrm{C}$. The chemical composition of the camshafts made of gray casting material is shown in Table I.

TABLE I

Chemical composition [\%] of gray cast iron camshaft.

\begin{tabular}{c|c|c|c|c|c|c|c|c}
\hline \hline $\mathrm{C}$ & $\mathrm{Si}$ & $\mathrm{Mn}$ & $\mathrm{P}$ & $\mathrm{S}$ & $\mathrm{Cr}$ & $\mathrm{Mo}$ & $\mathrm{Ni}$ & $\mathrm{Cu}$ \\
\hline 3.25 & 1.95 & 0.35 & 0.017 & 0.025 & 0.43 & 0.27 & 0.14 & 0.54
\end{tabular}




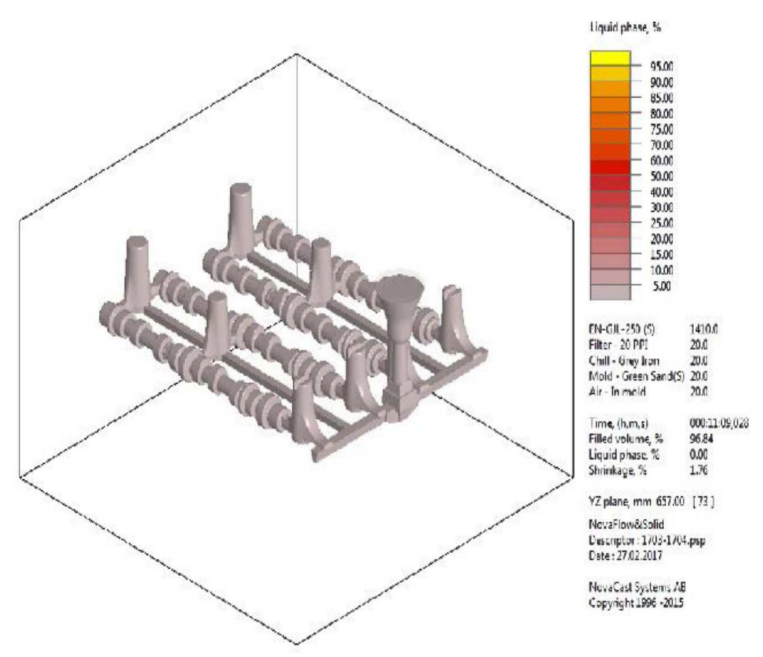

Fig. 1. Casting simulation.

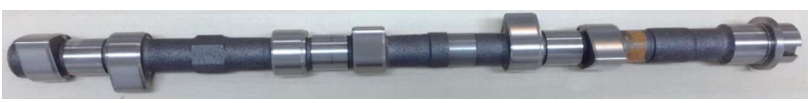

Fig. 2. Gray cast camshaft.

The measuring system consists of a vacuum pump, a gas distribution system, an energy source and a vacuum chamber made of stainless steel. The anode and cathode are placed in the vacuum chamber and the sample holder is used as the cathode. The thermocouple is connected to measure the temperature of the cathode. The samples are surrounded by a cylindrical anode. The cylindrical shape of the anode is to provide homogenous distribution of the resulting plasma to the sample.

$43 \mathrm{~mm}$ diameter, $47 \mathrm{~mm}$ high specimens were cut from the cast iron camshaft, grinded with 80-1200 sandpaper and polished with alumina powders of $5-3 \mu \mathrm{m}$ grains. The samples were cleaned with ethyl alcohol and were placed in a holder. The chamber was evacuated of air to a pressure of $3 \mathrm{~Pa}$ by means of a vacuum pump.

Carbon steel was used as the anode. Surface cleaning with $\mathrm{H}_{2}$ gas was carried out for 20 minutes with a low-current, high-potential DC $400 \mathrm{~V}$ voltage to remove contaminants from the specimens prepared before the ion nitriding process. After $\mathrm{H}_{2}$ gas was evacuated, the chamber was vacuumed again. Plasma nitriding was carried out according to the parameters given in Table II (see Fig. 3, 4).

Plasma nitriding test parameters

TABLE II (GG25 gray cast iron at $500^{\circ} \mathrm{C}$ ).

\begin{tabular}{c|c}
\hline \hline Nitriding duration & Gas mixing ratio \\
\hline $2 \mathrm{~h}$ & $80 \% \mathrm{H}_{2}+20 \% \mathrm{~N}_{2}$ \\
$4 \mathrm{~h}$ & $80 \% \mathrm{H}_{2}+20 \% \mathrm{~N}_{2}$ \\
$2 \mathrm{~h}$ & $90 \% \mathrm{H}_{2}+10 \% \mathrm{~N}_{2}$ \\
$4 \mathrm{~h}$ & $90 \% \mathrm{H}_{2}+10 \% \mathrm{~N}_{2}$ \\
$4 \mathrm{~h}$ & $94 \% \mathrm{H}_{2}+6 \% \mathrm{~N}_{2}$
\end{tabular}
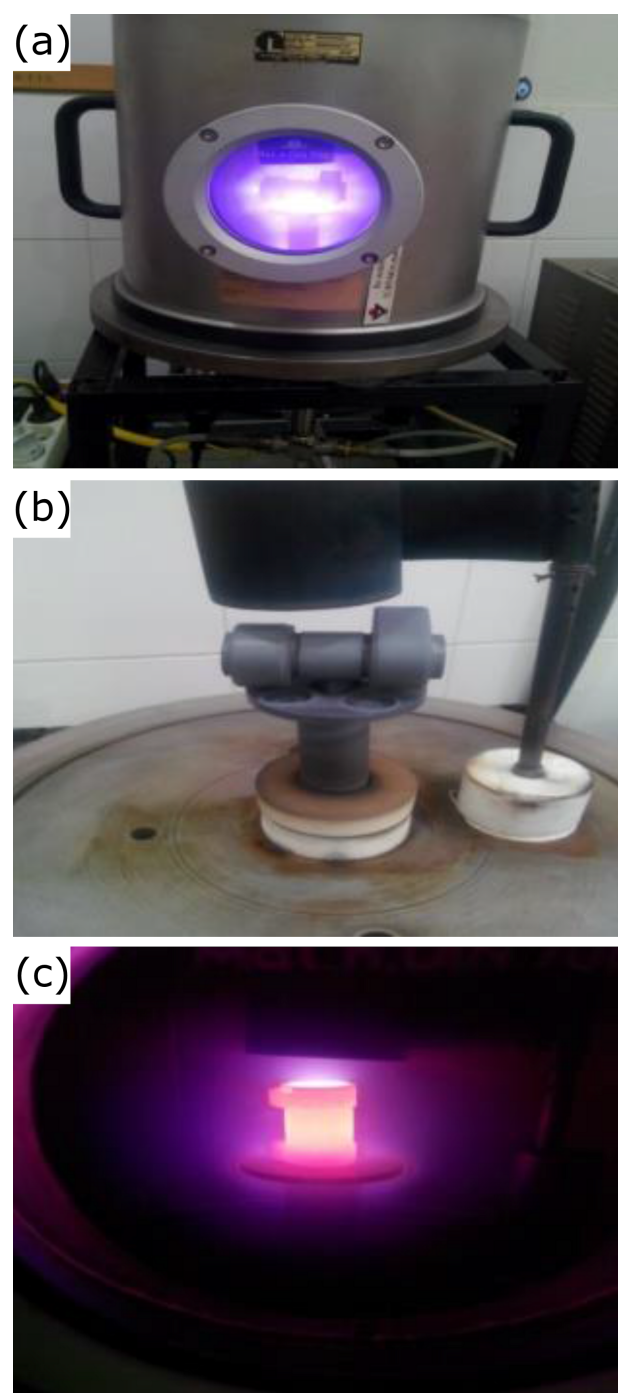

Fig. 3. Plasma nitriding application; (a) general view, (b) interior space, (c) vacuum environment.

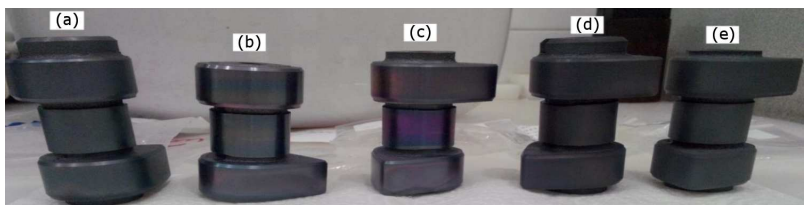

Fig. 4. Samples of cast iron camshaft nitrided under different conditions; (a) $80 \% \mathrm{H}_{2}+20 \% \mathrm{~N}_{2}$ for 2 hours, (b) $80 \% \mathrm{H}_{2}+20 \% \mathrm{~N}_{2}$ for 4 hours, (c) $90 \% \mathrm{H}_{2}+10 \% \mathrm{~N}_{2}$ for 2 hours, (d) $90 \% \mathrm{H}_{2}+10 \% \mathrm{~N}_{2}$ for 4 hours, (e) $94 \% \mathrm{H}_{2}+6 \% \mathrm{~N}_{2}$ for 4 hours.

Samples were taken from the non-treated and plasmanitrided cast iron camshafts and the phases formed on the part surface were determined using $\mathrm{Co}-\mathrm{K} \alpha$ radiation with a wavelength of $\lambda=1.790300 \mathrm{~A}$. Match! software was used to detect phases formed on the surface. The topographic views of the samples, microstructures and wear scars were observed using SEM (Scanning Electron Microscope). 
Hardness and diffusion layer thickness measurements were performed with a Qness Q10A microhardness tester under load of $10 \mathrm{~g}$ and load duration of $15 \mathrm{~s}$ in order to determine the surface hardness of the camshaft with no treated and plasma-nitrided specimens.

Hardness measurements were taken at specific distances towards the center of the sample to start from the outermost area. The hardness value measured near the surface was considered as surface hardness, and the distance to the core material hardness was determined as the depth of diffusion.

The cams were cut with a precision cutting device and flat surfaces were taken and their tribological properties were determined by carrying out wear. The wear volumes and surface roughness values of the samples were determined by Bruker brand 3D profilometer when the friction coefficient data were automatically taken from the machine. At room temperature, under load of $30 \mathrm{~N}$, rotation speed of $300 \mathrm{rpm}$, at 100 and $500 \mathrm{~m}$ distance, wear test with $100 \mathrm{Cr} 6$ material $5 \mathrm{~mm}$ in diameter was performed.

\section{Results and discussion}

X-ray diffraction analysis was carried out for the determination of the phases formed in the non-processed and plasma-nitrided cast iron camshaft. XRD patterns taken at $2 \Theta=10-100 \mathrm{deg}$ are given in Fig. 5. In the XRD plots, it was observed that the non-nitrided structure was composed of alpha-ferrite $(\alpha$-Fe) phase and only alphaferrite peaks were observed. Using the $94 \% \mathrm{H}_{2}+6 \% \mathrm{~N}_{2}$ gas mixture, on the surface of nitrated camshaft, $\alpha$-Fe, FeN0.09, Fe3N and Fe4N phases were observed during the 4 hour nitriding treatment period. As the process time increased, the concentrations of FeN0.09, Fe3N and $\mathrm{Fe} 4 \mathrm{~N}$ phases also increased. Both the increase in the process time and the increase in the amount of nitrogen in the gas mixture $\left(80 \% \mathrm{H}_{2}+20 \% \mathrm{~N}_{2}, 4\right.$ hours $)$ slightly increased the density of these peaks.

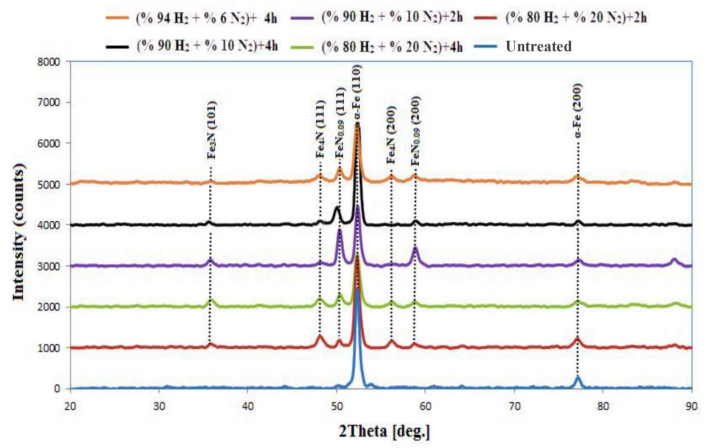

Fig. 5. XRD results of gray cast camshaft specimens nitriding and non-nitriting under different conditions.

Cross-sectional SEM images of the nitrated samples at different process parameters are given in Fig. 6. The thickness of the white layer ranges from 7 to 18 microns (Fig. 6a; $12 \mu \mathrm{m}$, Fig. 6b; $18 \mu \mathrm{m}$, Fig. 6c; $8 \mu \mathrm{m}$, Fig. 6d; $10 \mu \mathrm{m}$, Fig. 6e; $7 \mu \mathrm{m}$ ) depending on the nitriding time and gas mixture ratio. The thinnest white layer thickness $(7 \mu \mathrm{m})$ was observed in the $90 \% \mathrm{H}_{2}+10 \% \mathrm{~N}_{2}$ gas mixture for 4 hours of operation (Fig. 6d), while the thickest white layer thickness $(18 \mu \mathrm{m})$ was observed in the $80 \% \mathrm{H}_{2}+20 \% \mathrm{~N}_{2}$ gas mixture for 4 hours (Fig 6b). The increase in the nitrogen concentration and the process time in the gas mixture led to an increase in the phase density in the white layer and a growth in the layer thickness.

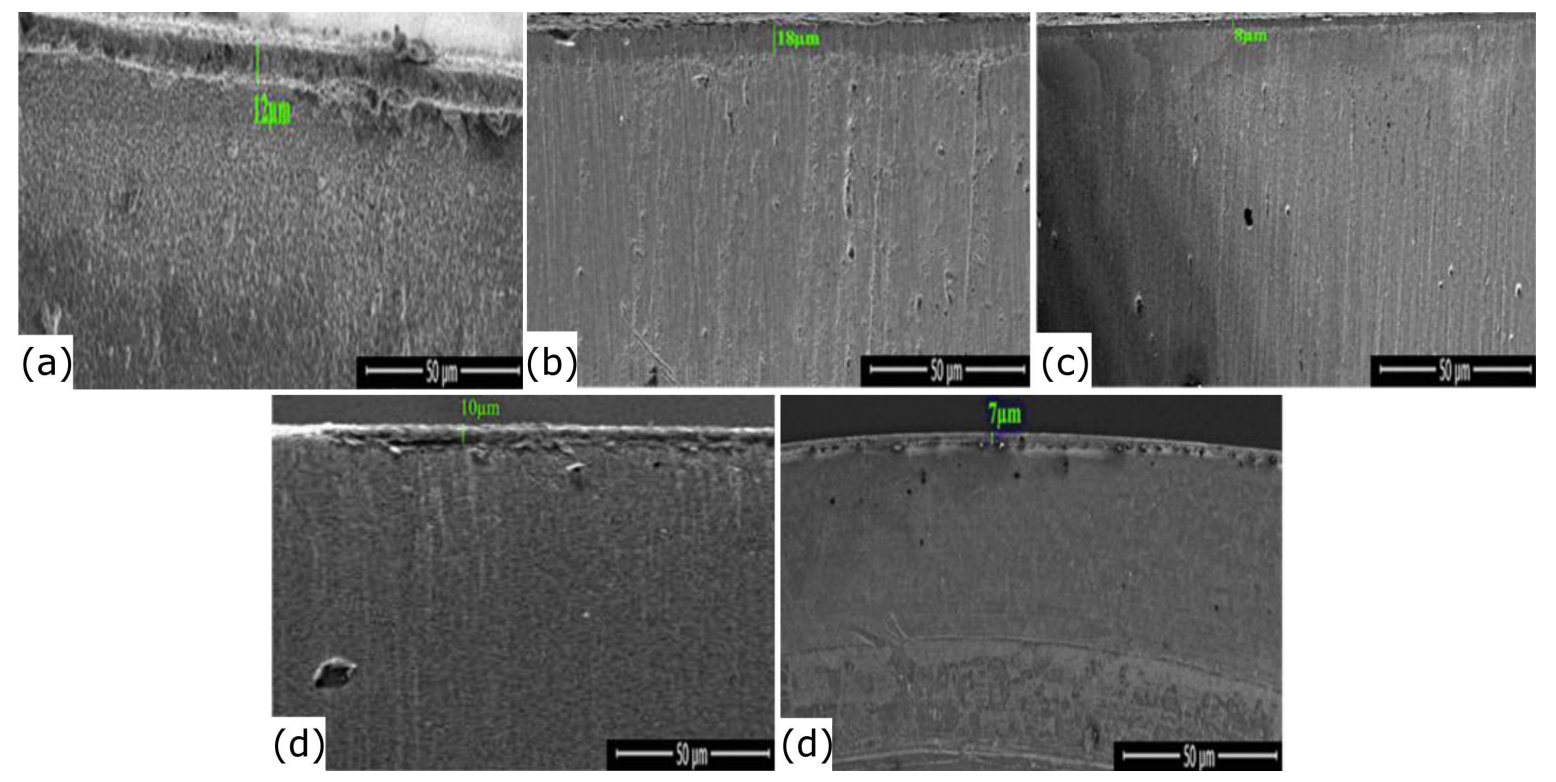

Fig. 6. SEM images of nitrided GG25 cast iron camshaft specimens; (a) $80 \% \mathrm{H}_{2}+20 \% \mathrm{~N}_{2}$ for 2 hours, (b) $80 \% \mathrm{H}_{2}+20 \% \mathrm{~N}_{2}$ for 4 hours, (c) $90 \% \mathrm{H}_{2}+10 \% \mathrm{~N}_{2}$ for 2 hours, (d) $90 \% \mathrm{H}_{2}+10 \% \mathrm{~N}_{2}$ for 4 hours, (e) $94 \% \mathrm{H}_{2}+6 \% \mathrm{~N}_{2}$ for 4 hours. 


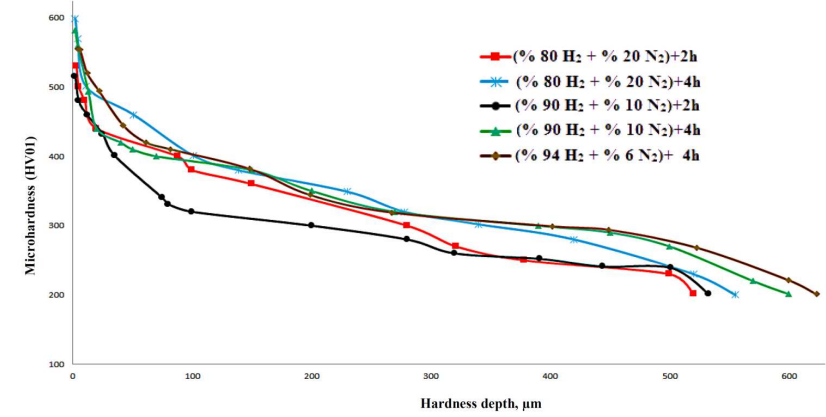

Fig. 7. Hardness distribution of gray cast camshaft samples nitrided with different conditions.

According to the measurement results shown in Fig. 6, the highest diffusion layer thickness $(603 \mu \mathrm{m})$ was obtained at $94 \% \mathrm{H}_{2}+6 \% \mathrm{~N}_{2}, 4$ hours nitriding conditions. Figure 7 shows the hardness distributions of the GG25 cast iron camshaft specimens. As the process is diffusional, increasing the amount of hydrogen in the gas mixture and increasing the process time, the nitrogen diffusing ability also increases and reaches deeper. Thus, as shown in Fig. 7, the hardness of the diffusion layer gradually decreases to the substrate material hardness value. The lowest hardness value (529 HV0.1) was measured in samples nitrated for 2 hours at $80 \% \mathrm{H}_{2}+20 \% \mathrm{~N}_{2}$ gas mixture while the highest hardness value (601 HV0.1) was observed in samples nitrated for 4 hours at $80 \% \mathrm{H}_{2}+20 \% \mathrm{~N}_{2}$ gas mixture. SEM images of the measured microhardness values are given in Fig. 8 (Fig. 8a; $480 \mu \mathrm{m}$, Fig. 8b; $500 \mu \mathrm{m}$, Fig. 8c; $530 \mu \mathrm{m}$, Fig. 8d; $560 \mu \mathrm{m}$, Fig. 8e; $603 \mu \mathrm{m})$.

The friction coefficient-wear distance graphs of the non-nitrated and plasma-nitrated samples of the cam against $\mathrm{Al}_{2} \mathrm{O}_{3}$ balls are given in Fig 9 . As a result of $100 \mathrm{~m}$ and $500 \mathrm{~m}$ distances under $30 \mathrm{~N}$ load, the mean friction coefficients of the untreated samples were 0.78 and 0.85 , respectively, while lower friction coefficients were observed in the plasma nitrided samples (Table III).

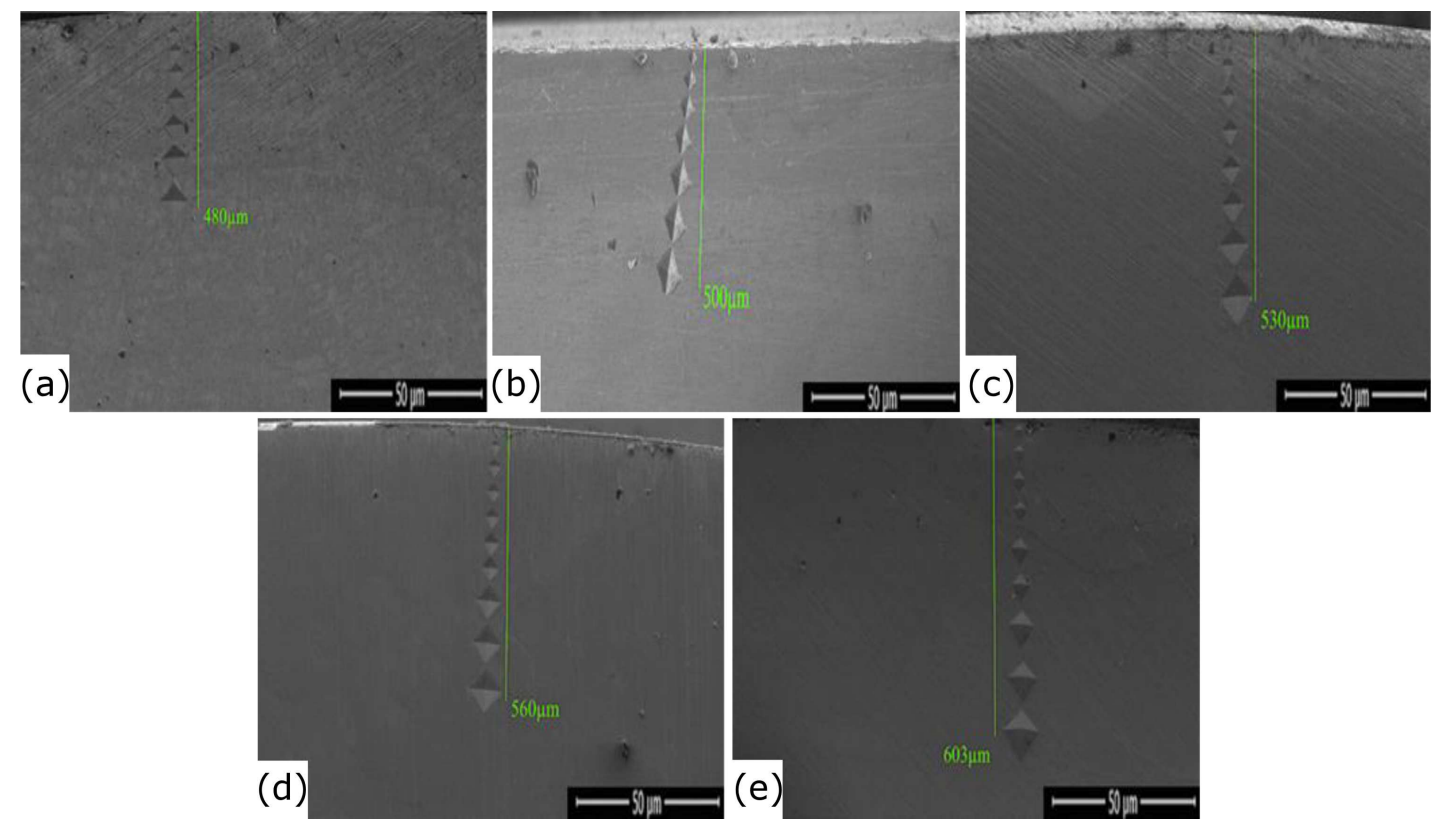

Fig. 8. Hardness depth SEM images of nitrided GG25 cast iron camshaft specimens; (a) $80 \% \mathrm{H}_{2}+20 \% \mathrm{~N}_{2}$ for 2 hours, (b) $80 \% \mathrm{H}_{2}+20 \% \mathrm{~N}_{2}$ for 4 hours, (c) $90 \% \mathrm{H}_{2}+10 \% \mathrm{~N}_{2}$ for 2 hours, (d) $90 \% \mathrm{H}_{2}+10 \% \mathrm{~N}_{2}$ for 4 hours, (e) $94 \% \mathrm{H}_{2}+6 \% \mathrm{~N}_{2}$ for 4 hours.

Test results applied to cast iron camshaft specimens with different plasma nitriding parameters.

TABLE III

\begin{tabular}{|c|c|c|c|c|c|c|c|c|c|c|c|}
\hline \multirow[t]{2}{*}{ Sample } & \multicolumn{3}{|c|}{ Nitriding parameters } & \multirow{2}{*}{$\begin{array}{c}\text { White } \\
\text { layer }[\mu \mathrm{m}]\end{array}$} & \multirow{2}{*}{$\begin{array}{c}\text { Diffusion } \\
\text { layer }[\mu \mathrm{m}]\end{array}$} & \multirow{2}{*}{$\begin{array}{c}\text { Surface } \\
\text { hardness } \\
\text { [HV01] }\end{array}$} & \multirow{2}{*}{$\begin{array}{c}\text { Surface } \\
\text { roughness } \\
{[\mu \mathrm{m}]}\end{array}$} & \multicolumn{2}{|c|}{$\begin{array}{c}\text { Friction } \\
\text { coefficient }\end{array}$} & \multicolumn{2}{|c|}{$\begin{array}{c}\text { Wear } \\
\text { loss [mg] }\end{array}$} \\
\hline & Temp. $\left[{ }^{\circ} \mathrm{C}\right]$ & Time $[\mathrm{h}]$ & Gas mixture & & & & & $100 \mathrm{~m}$ & $500 \mathrm{~m}$ & $100 \mathrm{~m}$ & $500 \mathrm{~m}$ \\
\hline 1 & 500 & 2 & $80 \% \mathrm{H}_{2}+20 \% \mathrm{~N}_{2}$ & 12 & 483 & 529 & 0.25 & 0.68 & 0.74 & 1.90 & 10.90 \\
\hline 2 & 500 & 4 & $80 \% \mathrm{H}_{2}+20 \% \mathrm{~N}_{2}$ & 18 & 501 & 601 & 0.29 & 0.61 & 0.65 & 0.80 & 5.50 \\
\hline 3 & 500 & 2 & $90 \% \mathrm{H}_{2}+10 \% \mathrm{~N}_{2}$ & 8 & 535 & 535 & 0.14 & 0.54 & 0.60 & 0.64 & 4.80 \\
\hline 4 & 500 & 4 & $90 \% \mathrm{H}_{2}+10 \% \mathrm{~N}_{2}$ & 7 & 559 & 555 & 0.18 & 0.49 & 0.54 & 0.40 & 3.10 \\
\hline 5 & 500 & 4 & $94 \% \mathrm{H}_{2}+6 \% \mathrm{~N}_{2}$ & 10 & 603 & 583 & 0.10 & 0.42 & 0.46 & 0.26 & 1.90 \\
\hline GG25 & 500 & - & - & - & - & 202 & 0.08 & 0.78 & 0.85 & 3.55 & 21.10 \\
\hline
\end{tabular}




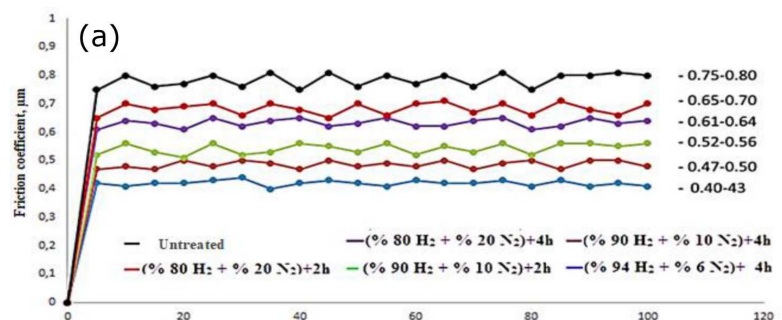

(b)

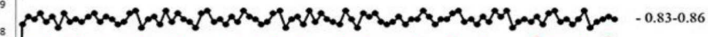

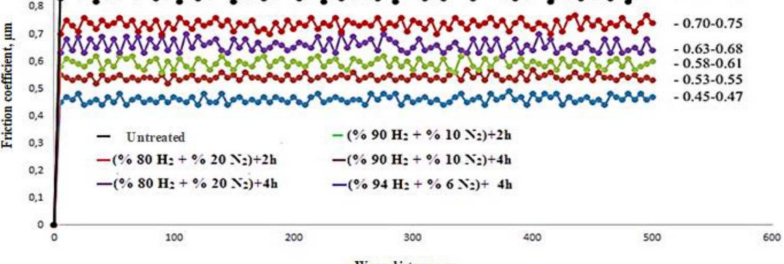

Fig. 9. Frictional coefficient-distance graph of GG25 camshaft specimens nitrided without process and under different conditions; (a) $100 \mathrm{~m}$, (b) $500 \mathrm{~m}$.

The surface hardness of the samples increased after the nitriding process and the increase in the treatment time from 2 hours to 4 hours decreased the friction coefficient with increasing surface hardness. The lowest friction coefficients were determined as 0.42 and 0.46 , respectively, in the 4 hour treatment period in the gas mixtures $94 \% \mathrm{H}_{2}+6 \% \mathrm{~N}_{2}$ at $100 \mathrm{~m}$ and $500 \mathrm{~m}$ distances.

Figure 10 shows the wear rates of the camshaft specimens after $100 \mathrm{~m}$ and $500 \mathrm{~m}$ distance under $30 \mathrm{~N}$ load. After the wear test, debris volume was determined with 3D contactless profilmeter. As can be seen in Fig. 11, the highest wear loss was seen in gray castings with low value of hardness. As the nitrided cam has a higher sur- face hardness, the wear loss of these camshafts is reduced. On the other hand, the lowest wear rate was observed in the samples nitrided with the highest percentage of hydrogen in the gas mixture. It is the result of the lowest surface roughness, even though the cam does not have the highest surface hardness.

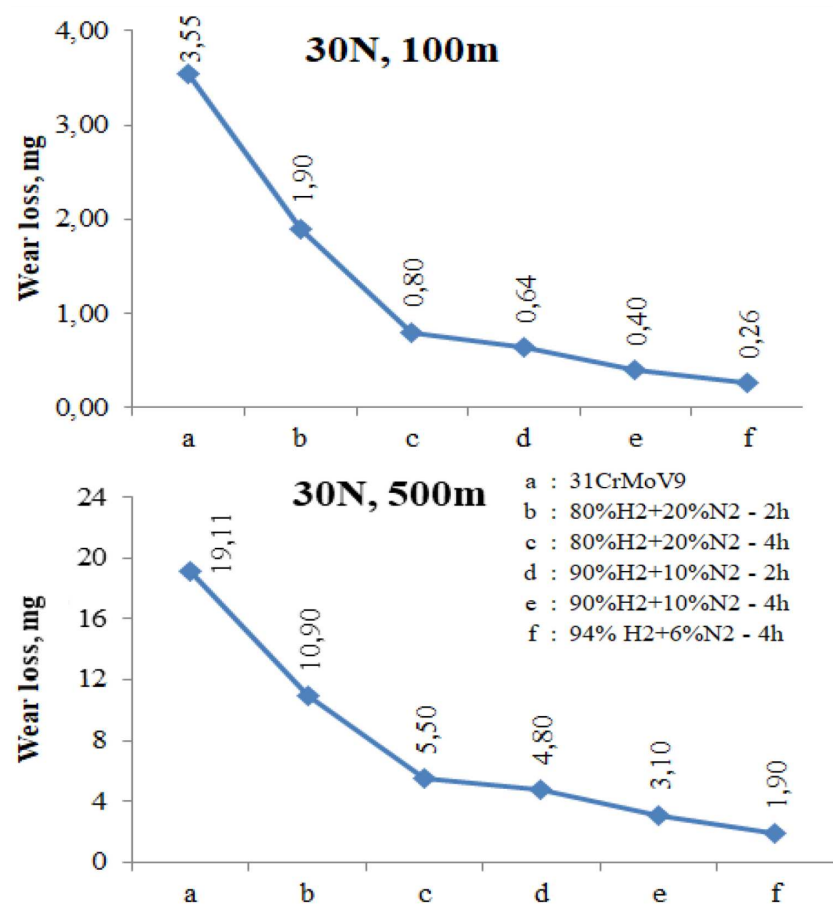

Fig. 10. Wear rates of GG25 cast iron camshaft specimens nitrided without process and under different conditions.
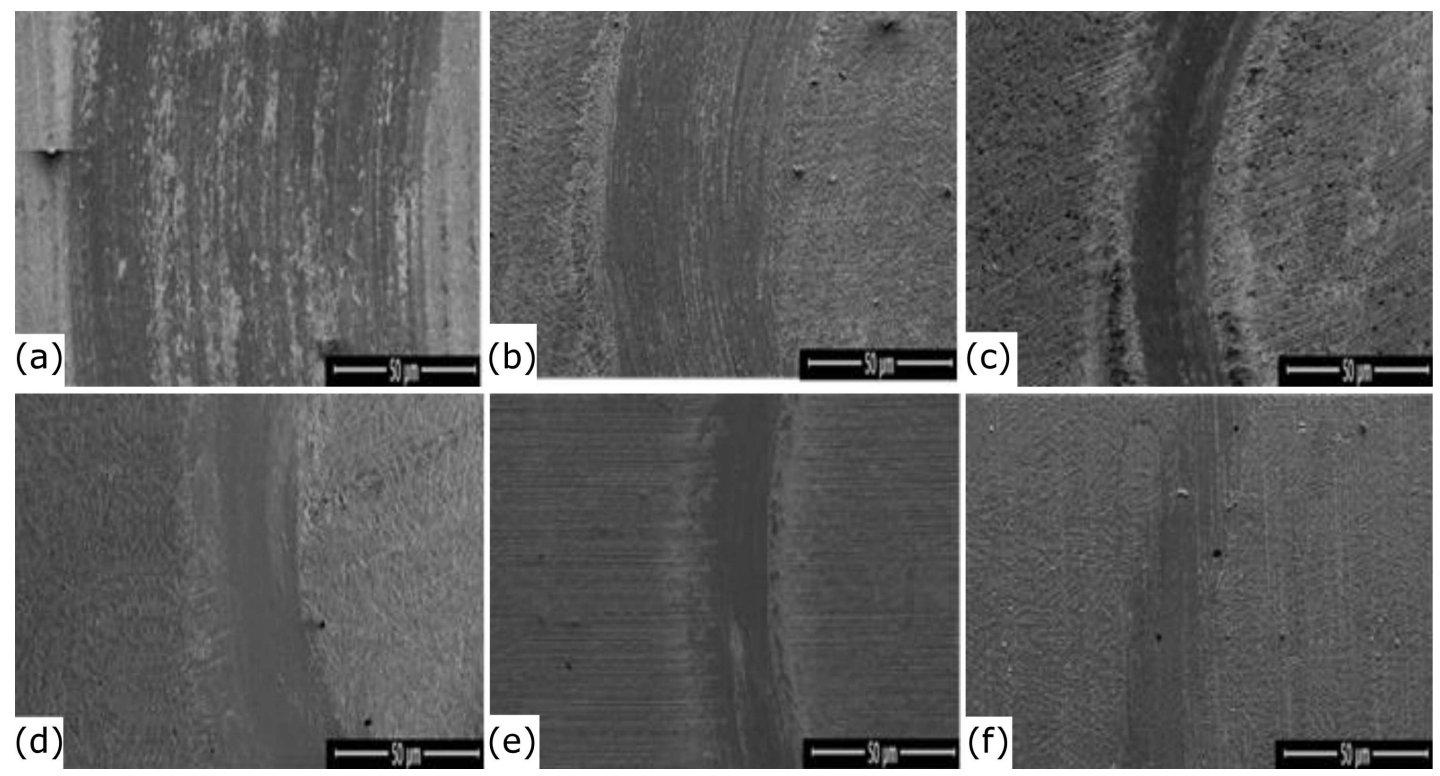

Fig. 11. Wear trace of SEM images of specimens of untreated and nitrated GG25 cast iron shaft without nitriding at $500 \mathrm{~m}$ distance; (a) untreated GG25 cast iron, (b) $80 \% \mathrm{H}_{2}+20 \% \mathrm{~N}_{2} 2$ hours, (c) $80 \% \mathrm{H}_{2}+20 \% \mathrm{~N}_{2} 4$ hours, (d) $90 \% \mathrm{H}_{2}+10 \% \mathrm{~N}_{2} 2$ hours, (e) $90 \% \mathrm{H}_{2}+10 \% \mathrm{~N}_{2} 4$ hours, (f) $94 \% \mathrm{H}_{2}+6 \% \mathrm{~N}_{2} 4$ hours. 
Figure 11 shows SEM images of samples nitrided under different conditions after a wear test at a distance of $500 \mathrm{~m}$. When worn surface images are examined, it is seen that the non-treated and nitrided cast iron exhibit different wear behaviors. The wear behavior of non-nitrided cast iron specimens (Fig. 11a) has the characteristic of abrasive wear. The wear behavior of nitrided specimens (Fig. 11b-e) is the adhesive wear. The signs of plastic deformation are clearly visible in the trace of wear of the non-processed sample. Moreover, the width of the wear trace is widening. After the nitriding process, the trace width of the samples decreases. The thinnest trace of wear was obtained from nitrated samples in a nitriding environment with a low percentage of nitrogen.
This situation can be explained by the reduction of the width of the wear allowance and the decrease in the surface roughness. The signs on the surface of the sample are partly accompanied by the presence of adherent layers and partial abrasive wear marks.

Figure 12 shows wear SEM images of GG25 cast iron camshaft specimens nitrided at 4 hours of operation in a $94 \% \mathrm{H}_{2}+6 \% \mathrm{~N}_{2}$ gas mixture tested at different wear distances. When the wear distance is increased from $100 \mathrm{~m}$ to $500 \mathrm{~m}$ (Fig. 12a-d), the width of the wear trace on the surface of both the cam and the machined cams increased. Partly abrasive scars of the presence of adhesive layers can be seen from the traces on the surface of the sample (Fig. 12a-c).
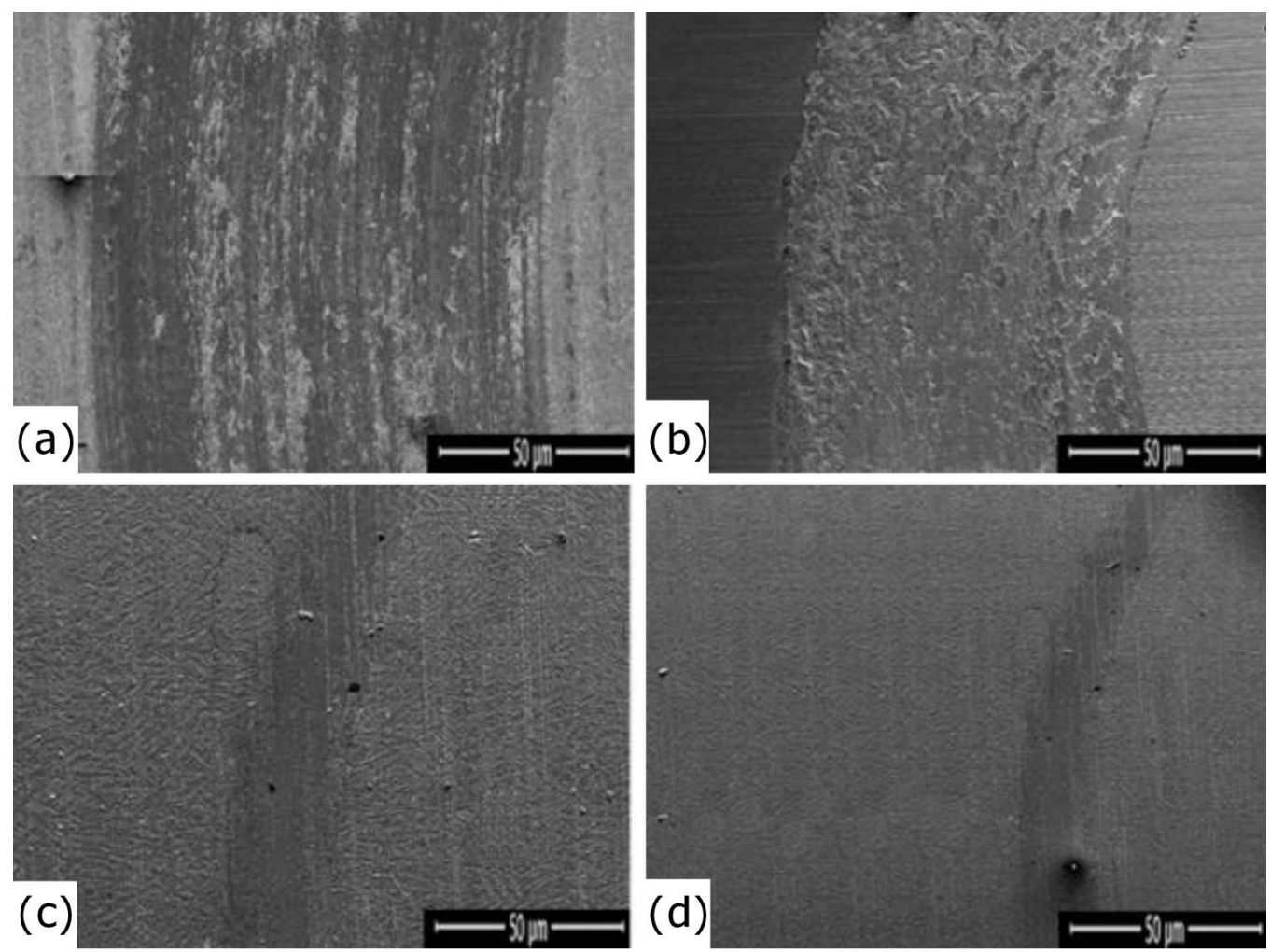

Fig. 12. Wear trace SEM images of non-treated and nitrided GG25 cast iron camshaft specimens; (a) Non-treated $500 \mathrm{~m}$, (b) Non-treated $100 \mathrm{~m}$, (c) $94 \% \mathrm{H}_{2}+6 \% \mathrm{~N}_{2} 4$ hours, $500 \mathrm{~m}$, (d) $94 \% \mathrm{H}_{2}+6 \% \mathrm{~N}_{2} 4$ hours, $100 \mathrm{~m}$.

\section{Conclusions}

In order to increase the mechanical and microstructure properties of the camshaft used in vehicle engines to higher levels, plasma nitriding processes were performed under different conditions. It is the process of choice for the steel materials. Recently, the nitriding process has started to be used in the surface treatment of casting materials. In this work, the camshaft made in gray casting process is used. This solution is aimed to improve the mechanical microstructure properties by nitridation at low temperature. Wear, hardness, surface properties and microstructures of the obtained samples were investigated and the results are listed below.
Alpha-ferrite $(\alpha-\mathrm{Fe})$ peaks were observed in XRD plots of samples of non-nitrided gray cast camshaft. Plasma nitriding of gray cast cam shaft specimens forms the modified layer consisting of $\alpha$-Fe, FeN0.09, Fe3N and Fe4N phases, depending on the process parameters on the surface of the material. It has been observed that these phases becomes more explicit with increase in the process time and the amount of nitrogen in the gas mixture. Plasma nitriding of gray cast camshaft specimens gives the thinner white layer of $10 \mu \mathrm{m}$ in $94 \% \mathrm{H}_{2}+6 \% \mathrm{~N}_{2}$ gas mixture and after $4 \mathrm{~h}$ nitriding run. The thickest white layer thickness was observed in the $80 \% \mathrm{H}_{2}+20 \% \mathrm{~N}_{2}$ gas mixture at $18 \mu \mathrm{m}$ in the 4 hour treatment run. The layer formed as a result of the nitriding process at the sur- 
face of the sample is separated from the GG25 cast iron base metal with a distinct line. The depth of the thinnest diffusing layer was found to be $483 \mu \mathrm{m}$ after 2 hour treatment process with $80 \% \mathrm{H}_{2}+20 \% \mathrm{~N}_{2}$ gas mixture. The thickest diffusion layer of $603 \mu \mathrm{m}$ was found after the treatment in $94 \% \mathrm{H}_{2}+6 \% \mathrm{~N}_{2}$ gas mixture.

The surface hardness of the gray cast camshafts is increased by using the nitriding process. The highest hardness value of 601 HV0.1 was observed in $80 \% \mathrm{H}_{2}+20 \% \mathrm{~N}_{2}$ gas mixture, after 4 hour treatment run. The highest hardness depth was observed in the $94 \% \mathrm{H}_{2}+6 \% \mathrm{~N}_{2}$ gas mixture during the 4 hour treatment run. For this reason, the depth of hardness is thought to be more important. Gray cast iron camshafts were subjected to tests to measure wear resistance at $100 \mathrm{~m}$ and $500 \mathrm{~m}$ slip distances under load of $30 \mathrm{~N}$. According to these test results, it was determined that wear resistance increases due to the applied plasma nitriding process. The best abrasion resistance was observed in $94 \% \mathrm{H}_{2}+6 \% \mathrm{~N}_{2}$ gas mixture during 4 hour treatment period as $1.90 \mathrm{mg}$ at a distance of $500 \mathrm{~m}$. It has also been observed that the abrasion resistance increases with the increase in the nitriding process time. The coefficient of friction is reduced due to the reduction of the surface adhesion forces of the sample and formaton of the hard thin layer of nitrides.

\section{References}

[1] W. Gui, J. Lin, Sci. Rep. 7, 165 (2017).

[2] S. Q. Wang, M.X. Wei, Y. T. Zhao, Wear 269, 424 (2010).

[3] D.J. Shen, Y.L. Wang, P. Nash, Mat. Sci. Eng. A 458, 240 (2007).

[4] M.D. Bermúdez, P. Iglesia, A.E. Jiménez, Wear 267, 1784 (2009).

[5] C.C. Wang, J.R. Hwang, Surf. Coat. Tech. 64, 29 (1994).

[6] V.N. Duradji, D.E. Kaputkin, J. Electr. Soc. 163 306 (2016).

[7] S.F. Luk, T.P. Leung, W.S. Miu, J. Mat. Proc. Tech. 63, 833 (1997).

[8] J. Suchanek, V. Kuklik, Wear 267, 2100 (2009). 